\author{
Sylwia STRASZAK-CHANDOHA, PhD \\ Faculty of Economic Sciences, Wrocław Univeristy of Economics \\ e-mail: sylwia.straszak-chandoha@ue.wroc.pl \\ ORCID: 0000-0002-3220-9533
}

DOI: $10.15290 /$ oes.2019.04.98.12

\title{
AN ANALYSIS OF THE DEVELOPMENT IN AGRICULTURE IN LOWER SILESIA FROM 1918 TO 1939 AND 1945 TO $1956^{1}$
}

\begin{abstract}
Summary
Purpose - An analysis of the development in Polish agriculture from 1918 to 1939 and 1945 to1956.

Research method - The article uses scientific historical and economical methods. Source texts of the state provenance were analysed: legal acts, printed sources (mainly statistical), archival records. In the economic studies, the analysis included statistical data, dynamics of phenomena, and comparative studies.

Results - The analysis of changes in agriculture in Lower Silesia in the studied periods demonstrates that despite the under-investment and its marginal economic importance in Germany from 1918 to 1939, the agriculture in Lower Silesia was at a much higher level than the agriculture in pre-war Poland. Communism coming into power post 1945 and Poland entering the so-called Eastern Block hindered further development of capitalist agriculture in Lower Silesia. The agricultural structure created after World War II was not adapted to the character of farms taken over and the existing agricultural system was completely different from the socio-political assumptions based on agricultural reform and on the socialist character of agriculture prevailing from 1945 to 1956.

Originality / value - The analysis of agricultural economy in the studied period was not sufficiently described in the source literature.
\end{abstract}

Key words: agrarian structure, collectivisation, agrarian reform, peasant farming, production cooperatives, National Agricultural Farms

JEL Classification: H71, H26, H72, P32, Q13, Q15

\section{Introduction}

The political and economic situation in Lower Silesia in the period from 1918 to 1939 differed significantly from the position during 1945 to 1956 . Prior to 1945, Lower Silesia was a part of a capitalistic state and such was also its character, despite the fact that it constituted a peripheral eastern region of the Third Reich, having

\footnotetext{
1 Article received on 21 May 2019, accepted on 9 September 2019.

Article financed by the research project no. 2015/17/N/HS3/00882 of the National Science Centre

"Economic and socio-political factors of changes in agriculture in Lower Silesia in 1945-1956".
} 
a marginal importance in its social and economic life. However, the level of its agricultural production surpassed the agricultural activity in Poland during the interwar period (1918-1939). In the present study, the agrarian structure, level of mechanisation, fertilisation and breeding were analysed. Conclusions concerning the level of agricultural production from 1918 to 1939 in Lower Silesia determined the situation of agriculture in this area after 1945. A symbolic "closing" balance sheet of German presence in this area was made and later utilised as a reference point to assess the situation of agriculture after 1945. After 1945, Lower Silesia became a part of a state which gradually introduced a socialist economy. The purpose of the analysis of the studied period was to demonstrate to what degree agriculture in Poland had a sufficient production base allowing it to satisfy the needs for production means (machinery, tools, fertilizers, etc.).

\section{Agriculture in Lower Silesia in the period from 1918 to 1939}

Before 1939, the area of Lower Silesia belonged to the eastern periphery regions of Germany. With the exception of a few industrial micro-regions, it was predominantly an agricultural area. As per official census data, the agrarian structure of the Lower Silesian province included a high number of micro farms ("dwarf farms") below 2 ha, which constituted ca. $50 \%$ of the total number of all farms, and which occupied only $4 \%$ of the land. Agriculture was based on large farms of more than 100 ha, which in 1938 covered $48.1 \%$ of the total area and constituted slightly more than $1 \%$ of the total number of farms [Fiedor, 1965, p. 38]. In comparison to Western Pomerania or the Masurian District, Lower Silesia had a lower percentage of latifundium type farms (in Polish "folwark"), large peasant farms (5-20 ha) and small peasant farms. The largest percentage share of farms smaller than 5 ha were located in the districts of Głogów, Wałbrzych and Legnica. Micro farms were also numerous in the vicinity of large cities, such as Swidnica, Legnica, Wrocław, Wałbrzych and Brzeg. Large peasant farms were the most numerous in the districts of Wrocław, Ząbkowice, Brzeg and Złotoryja. Properties above 100 ha dominated the districts of Wrocław, Ząbkowice, Głogów, Jawor, Strzelin, Trzebnica and Wołów.

Out of all eastern provinces, in Silesia we find the highest share of people employed in industry and craft, which provided income for $36.9 \%$ of population [Buławski, 1946, p.19]. It resulted from the fact that this area housed two strong industrial micro-regions, i.e. the Upper Silesian Basin and the Wałbrzych Basin. According to data from 1939, the local population employed in agriculture and forestry (professionally active and passive) constituted ca. 23\% of the total number of people in employment. Fiedor [1965, p. 35] states that $27.4 \%$ of the Lower Silesian population worked in agriculture and forestry, $37.2 \%$ earned their living in industry and craft, $15.7 \%$ in trade, $6.2 \%$ were employed in administration, army, health care and freelance jobs, 3.6\% worked within domestic service, and $9.9 \%$ did not have a profession. There were 27.4 farmers per $1 \mathrm{~km}^{2}$. In comparison to the 
total population, farmers constituted $22.6 \%$ [Styś, 1948, pp. 247-296], which constituted a slightly higher percentage than in other regions of the Reich, where in 1933, the share of farmers amounted to $20.9 \%$ with a decreasing tendency. A comparison of this data with Poland, which in 1931 had $60.6 \%$ of farmers [Kościk, 2010, pp. 298-299], that is ca. 50 farmers per $1 \mathrm{~km}^{2}$, leads to a conclusion that Silesian farms were definitely larger than Polish. Secondly, a crucial factor influencing the economic situation of German eastern provinces was the insufficient number of people living on these territories. Population density calculated for the whole territory of the then Eastern Germany amounted to 95 people per $1 \mathrm{~km}^{2}$. The insufficient number of people on the eastern borderland of Germany is evident after calculations undertaken in 1938 of arable land per 1 inhabitant. In Western Germany the figure amounted to 0.367 ha per person, in the central part of Germany 0.347 ha, and in Eastern Germany - 0.748 ha per person [Gleitze, 1956, pp. 36-37]. The professional structure of the Silesian population was distinctively different from the population structure in Poland with the percentage of people employed in agriculture being significantly lower. Furthermore, this number decreased each year as a result of the development of capitalistic economy, increasing industrialisation in the second half of the 19th century and at the beginning of the 20th century, modernisation, the intensification of agricultural production and the import of inexpensive American and Russian cereals to the Reich. In 1925, farmers constituted $28.5 \%$ of the population, while in comparison it was only $22.4 \%$ in 1939 [Jagielski, 1958a, p. 189]. Czapliński reports that in 1931, in Silesia only $12.3 \%$ earned a living in agriculture and forestry [Czapliński, 2007, p. 439]. Despite this, there was an increase in the relative number of people professionally active in agriculture: in 1925 they amounted to 68.8\%, and in 1939 to $71.1 \%$ [Gleitze, 1956, pp. 189-190; Statistisches Jahrbuch...,1939, p. 373-379]. Most probably, the reason was related to shifts in the age structure of the population and a higher engagement of women in professional work. The inter-war period in Silesia is the time of a constant outflow of people at the production age to western regions of the Reich [Kokot, 1955, pp. 465-466]. Concurrently, many people migrated from rural areas into cities. Also, there was an economic migration of Polish farm workers who were mostly employed in eastern provinces of the Reich. The phenomenon of Ostfluch (i.e. the flight from the East, i.e. the outflow of people from Silesia to the west) discussed by Brożek [1966], and Bechtel [1933/1934, p. 69] defines this idea (with reference to Lower Silesia) as "an outflow of people entering the money-making zone from their motherland province to Central and Western Germany". The growing deficiency of labour to work in German agriculture of the eastern provinces facilitated certain beneficial economic processes, such as the mechanisation of big land estates and farms, as well as the intensification of agricultural production. They caused further changes which manifested at the beginning of the 20th century in transformations taking place in the agrarian and social structure of rural areas.

The development and profitability of farms depended not only on the soil quality and the acreage of arable land, but also on the opportunities to sell their produce, as well as agriculture policy of the state. Despite the fact that Lower Silesia was 
supposed to be the agricultural hinterland for the industrial regions of Saxony and Berlin, its unfavourable geographical location (far from major urban centres) impeded the transport of agriculture and food products further west in the Reich. In the 1920s, the agricultural market in Lower Silesia also suffered from the negative impact of the unemployment in the industrial micro-region of Wałbrzych [Kouli, 2018, p. 204]. Pauperisation of industrial workers considerably reduced their purchasing power. It resulted in a lower demand for agricultural and food products, which had to be price-wise attractive. This was difficult to achieve due to increasing transport costs and inflation after World War I. Furthermore, the price scissors opened, e.g. compared to the pre-war period, the price of coal increased by $148 \%$, and construction materials by $211 \%$, while the prices for cereals and livestock remained at the same level [Fiedor, 1965, p. 39]. In Lower Silesia, farmers often protested against the import of less expensive agricultural and food products, for example from Poland [Was ist mit..., 1928, p. 14]. Increasing agricultural taxes constituted an additional burden for farming in Lower Silesia. On average, in 1924/1925, the tax per 1 ha amounted to 18 marks, and in the following years it increased four-fold; in 1929/1930 it was as high as 70 marks per 1 ha [Pismo ₹..., 1931, p. 34].

The German government introduced various aid programmes for agriculture. In 1925, a plan to recover the German economy, developed by American bankers and called the Charles Dawes Plan was implemented. It included a series of foreign loans for the German economy amounting to ca. USD 800 million. Unfortunately, this plan did not contribute to a considerable improvement of the situation in the Lower Silesian rural areas. In 1926, new import duties for agricultural products were introduced, however the result of that decision was noticeable only at the end of the 1920 s, but was also related to the introduction of a higher land tax, which impeded the development tendencies in Lower Silesian agriculture. The intended solution to the problem was the "assistance programme for eastern provinces", i.e. Ostpreußenbilfe and later Ostbilfe (pursuant to the regulation issued by the President of the Reich on 26 July 1930). However, they were programmes which mostly supported large farms and land estates in Eastern Prussia [Fiedor, 1965, pp. 41-42], and affected mainly a large number of consumers, predominantly peasant farms. The new agricultural policy of the Third Reich after 1933, aimed to balance agriculture and industry did not considerably alter the situation in the Lower Silesian rural areas. However, the intervention policy of inexpensive investment goods and the introduction of fixed prices (the system was based on the principle of covering production costs) allowed for the intensification of agricultural production and increasing self-efficiency of the German state with respect to food products and animal feed [Jagielski, 1958, pp. 302-303]. In 1934, to protect farms based on hired labour, it was forbidden to employ agricultural workers outside the sector, hence forcing them to stay with the estates which employed them, and as a result limiting their migration and employment to other branches of the economy [Kouli, 2018, pp. 64-65]. This regulation only to a small degree mitigated the existing crisis with respect to labour. Difficulties in obtaining loans and securing labour were among 
the reasons which contributed to the break up of large estates in the Silesia region. The situation of agriculture in Lower Silesia improved after 1937 thanks to the intensification of production, better fertilisation and the development of local agricultural and processing markets. Thanks to climatic conditions, short winters, relevant rainfall and sun exposure, the basic crops yield per hectare increased considerably. Higher yield per hectare was also related to fertilizers and mechanisation. Fertilizers in Lower Silesia were more frequently used on large agricultural enterprises, rather than on peasant farms. Obviously, this was related to the acreage and costs involved. Interesting data is quoted by Fensch [1932] who calculated according to closing balance sheets, that farms of more than 200 ha spent less on artificial fertilizers than larger peasant farms. This phenomenon can only be explained by the fact that they purchased large volumes and were in the position to negotiate lower prices per $1 \mathrm{~kg}$ of fertilisers per hectare [Jagielski, 1958, pp. 260-261]. Higher usage of fertilizers per 1 ha was accompanied by a growth of productivity and profitability. The mechanisation of agriculture also contributed to the intensification of agricultural production. Despite the fact that the area of Eastern Germany (Upper and Lower Silesia) had the lowest level of mechanisation and the most limited machinery backup, in 1939, per $1 \mathrm{~km}^{2}$ there were 15.7 machines with electrical engines of the power below $6 \mathrm{HP}$ (for comparison: 62.6 machines per 1 ha in the western part of Germany); 28.3 machines with engines above $6 \mathrm{HP} ; 49$ steam powered tractors (locomobiles); 10 small tractors of the power ranging from 8 to 22 HP per hectare; and 29.1 field tractors of the power above 22 HP [Gleitze, 1956, p. 161]. Fertilizers in Lower Silesia were more frequently used on large agricultural enterprises than on peasant farms. This can be attributed to the acreage and costs involved.

Livestock was another factor which influenced the effectiveness of agriculture. The development of animal breeding in Silesia depended to a large degree on the level of supplies of animal produce to the German market. Due to a greater percentage of urban population in Germany, the demand for meat and animal produce increased. A great obstacle for the development of animal breeding was insufficient animal feed backup and competitive imported goods [Meyer, 1939, p. 441; Jagielski, 1958, pp. 262-263]. Natural conditions of Lower Silesia did not facilitate animal breeding, either. The area did not have sufficient acreage of grassland and pastures, even in the hill districts where the percentage of this type of agricultural land was the highest (it was only slightly higher than $15 \%$ of the total area). Nevertheless, as a result of the high standard of agricultural culture in Lower Silesia in that period, the density of domestic animals was very high. Farms with acreage above 2 ha bred mainly horses (i.e. $98.8 \%$ in 1933) and mainly horned cattle (i.e. $97.1 \%$ in 1933). The share of micro farms was visible if we take into consideration the number of cows or pigs, which amounted to $5.8 \%$ of the total number in 1933. Pigs production was mostly concentrated on medium size farms. On 100 ha of arable land, they were the most numerous on peasant farms and large peasant farms, while smaller numbers concentrated on large agricultural estates [Jagielski, 1958a, p. 219]. It should be stressed that the development of pig breeding was stimulated by the reserves of 
potatoes remaining every year. A similar situation concerned the horned cattle. An average number of animals per 1 farm increased as per the size of its acreage. However, horses were concentrated on medium and big peasant farms and on large estates.

The composition of livestock in Lower Silesia differed from other regions. Farms of Lower Silesian rural areas owned a larger number of livestock, mainly cattle and pigs, whose better quality was visible in the standard of wool (cattle), meat and the milkability of cows. Whereas in Poland in 1934, the average cow's milakability was estimated at the level of 1250 litres per year, in Lower Silesia it amounted to 2120 litres, i.e. $70 \%$ more. In 1935, the production of milk per 1 ha of arable land amounted to 351 litres [Straszak-Chandoha, Merta-Staszczak, 2018, p. 160], while in Lower Silesia it amounted to 802 litres, which is more than twice as much [Styś, 1948, p. 275; Jagielski, 1958, p. 269]. The distribution of cattle in Lower Silesia was not uniform. The largest density was observed in mountain districts, which had superior soil and climate conditions due to a larger number of grassland and pastures (district of Jelenia Góra - 80 heads of cattle and 45 heads of milky cows per 100 ha; districts of Kłodzko, Dzierżoniów, Nysa, Prudnik, Głubczyce, Zabkowice - more than 60 heads per 100 ha) [Jagielski, 1958, p. 270].

TABLE 1

\section{Headage of livestock in Lower Silesia in 1937}

\begin{tabular}{|c|c|c|c|c|c|c|c|c|c|c|}
\hline \multirow[b]{3}{*}{ Area } & \multicolumn{2}{|c|}{ Horses } & \multicolumn{4}{|c|}{ Horned cattle } & \multicolumn{2}{|c|}{ Pigs } & \multicolumn{2}{|c|}{ Sheep } \\
\hline & \multirow[b]{2}{*}{ Total } & \multirow[b]{2}{*}{ 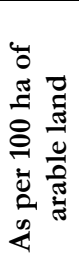 } & \multicolumn{2}{|c|}{ Total } & \multicolumn{2}{|c|}{ Cows } & \multirow[b]{2}{*}{ Total } & \multirow[b]{2}{*}{ 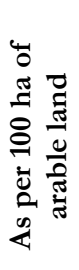 } & \multirow[b]{2}{*}{ Total } & \multirow[b]{2}{*}{ 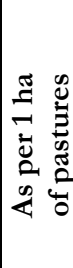 } \\
\hline & & & Total & 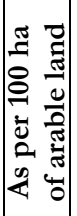 & Total & 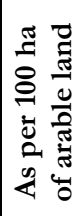 & & & & \\
\hline $\begin{array}{l}\text { Breslauer } \\
\text { Regierungsbezirk } \\
\text { (Middle Silesia) }\end{array}$ & 115871 & 12.7 & 637321 & 69.8 & 314553 & 34.4 & 742821 & 81.3 & 98610 & 3.7 \\
\hline $\begin{array}{l}\text { Liegnitz } \\
\text { Regierungsbezirk }\end{array}$ & 83428 & 11.0 & 541108 & 71.3 & 277565 & 37.9 & 567370 & 74.7 & 81599 & 3.0 \\
\hline Poland & 3889263 & 14.5 & 10572505 & 40.0 & n.d. ${ }^{a}$ & n.d & 7696283 & 29.0 & 3188066 & 1.3 \\
\hline
\end{tabular}

a Statistical yearbooks do not include data on the number of cows; they only record the total number of horned cattle.

Source: own elaboration on the basis: [Statistisches Jabrbuch..., 1938, pp. 116-119; Rocznik statystyczny..., 1939, pp. 45-48].

In Lower Silesia, there were fewer horses per 100 ha than in Poland (table 1). This was due to a number of factors. The most important one was the well developed network of roads and railways, as well as a relatively well extended vehicle fleet which resulted in reducing the use of horses for transport. In the 1930s, 
mechanisation in agriculture replaced to a large degree horse labour in farming. An important factor was also the quality of working horses (they were stronger) and the fact, that frequently cows and oxen were used as draft animals on small farms.

\section{3. "Opening balance of accounts" for Lower Silesia agriculture in $\mathbf{1 9 4 5}$}

During World War II, similarly to industry, the agriculture in Lower Silesia was transformed to work for the needs of the army. The main challenge for farms in this period was the shortage of labour as a result of the general mobilisation. From 1939 to 1944, Lower Silesia belonged to the undisturbed areas of the Third Reich. The situation changed towards the end of the war, when the war front moved and during the siege of Wrocław at the turn of 1944 and 1945, when a considerable part of the city was demolished. The Germans took part of machinery and plant from industrial factories to West Germany, while the remaining part was demolished due to strategic reasons. The southern district of Lower Silesia suffered the least damage, since the German army residing there in May 1945 capitulated in front of the Western Allies. A large part of assets in the form of land and buildings was seized by the Red Army until the 1980s.

The livestock suffered the most, being almost completely exterminated. In 1945, the headage of cattle in Lower Silesia amounted to hardly $10.8 \%$ of the pre-war volume (108,000 heads); in the case of pigs it was only $1.6 \%$ of the pre-war volume (16,000 heads); horses - 15\% (from 186,047 horses in 1939, their population dropped to 28,076 in 1945) and 3\% sheep [Statystyka dotyczaca inwentarza..., p. 2; Kapusta, 1980, p. 9; Kaliński, 1995, p. 9; Ordyłowski, 1999, p. 15; Łach, 1965, p. 15]. In other parts of Poland, in the autumn of 1945, the loss in livestock was estimated as follows: cattle $-48 \%$, pigs $-31 \%$, horses $-58 \%$ [Kłusek, 2013, p. 15]. In the Wrocław region, the following districts suffered the largest loss in livestock: Bolesławiec, Dzierżoniów, Góra Śląska, Jawor, Legnica, Lubin, Lwówek, Strzelin, Środa Śląska, Świdnica, Wołów, Wrocław, Zgorzelec and Złotoryja. In those districts, there were fewer than 15 heads per 100 ha of arable land, so on average there were 1.7 calculative head per one 10 ha farm [Fiedor, 1965, pp. 54-55]. In 1945, in those districts, also due to settlement challenges, harvesting covered less than $10 \%$ of arable land. A good example is Bystrzyca, where despite the level of $66 \%$ of the horses' volume in comparison to the pre-war times, there were only 2,335 horses per 3,371 farms [Pismo Petnomocnika..., 1946, p. 338]. The situation of the districts of Kłodzko, Jelenia Góra, Wałbrzych or Lubań was much better, where there were 50 horses per 100 ha of arable land [Kapusta, 1980, p. 9]. Hill and foreland districts suffered the least during the war activities, and the livestock level, as well as the condition of buildings and facilities was more favourable there. The situation improved after one year of settlement action when some livestock arrived with re-settlers; furthermore, a large number of livestock was also provided for farmers from Lower Silesia within UNRRA commodity aid. 
According to the 1947 statistical yearbook, in the Wrocław region, the damage affected 42,7 thousand farms and the loss amounted to 330 million zloties of 1939 [Rocznik statystyczny...,1948, p. 39]. Many residential and farming buildings were destroyed, i.e. $25.6 \%$ of farms [Pismo Departamentu.., 1948, p. 89], including 42,000 farms which were seriously damaged and 54,000 were totally destroyed [Pismo o reformie..., 1948, p. 93].

A characteristic feature of the German agrarian structure was a large percentage of big farms of 20-50 hectares. In relation to their acreage, those farms had well developed farmhouses and facilities which were more modern than farms, for example, in Central Poland. Almost all of them had electricity, drainage and water supply systems, as well as automatic watering systems in cowsheds, hay hoists and the like. The value of developments on those farms was so high that it often was higher than the value of the land belonging to such a farm [Zagadnienie podriatu..., 1948 , p. 26]. By creating a new structure based on smaller farms, the authorities were forced to allocate farms adjusted for one-family farming to two, three, four or even five settlers (the issue of dividing one farm among few settlers was finally regulated by the instruction of the Minister of Agriculture and Agricultural Reforms of 12 May 1948). In practice, the most frequent way of resolving the problem of multi-family farms was to keep one settler as the owner and the other families had the right to live there for 5-10 years, with a separation of new building plots on the land. There were also cases of keeping few settlers as co-owners. Some parts of the land which were subject to the agricultural reform were separated to create state owned farms, and the remaining land was designated for ownership for coming settlers, providing them with farms ranging from 7 to 15 ha.

TABLE 2

Structure of individual farms as per the acreage in the Wrocław region
and in Poland from 1950 to 1960 (in \%)

\begin{tabular}{|l|l|c|c|c|c|c|}
\hline \multirow{2}{*}{ Yeras } & \multirow{2}{*}{ Specification } & \multicolumn{5}{|c|}{ Acreage groups as per total area (ha) } \\
\cline { 3 - 7 } & & $\mathbf{2}$ & $\mathbf{2 - 5}$ & $\mathbf{5 - 7}$ & $\mathbf{7 - 1 0}$ & $>\mathbf{1 0}$ \\
\hline \multirow{3}{*}{1950} & Wrocław region & 24.0 & 18.6 & 18.0 & 33.4 & 6.0 \\
\cline { 2 - 7 } & Poland & 25.9 & 31.3 & 15.1 & 15.7 & 12.0 \\
\hline \multirow{2}{*}{1960} & Wrocław region & 36.1 & 20.1 & 13.5 & 21.9 & 8.4 \\
\cline { 2 - 7 } & Poland & 32.8 & 30.4 & 13.2 & 12.9 & 10.7 \\
\hline
\end{tabular}

Source: own elaboration on the basis: [Rolniçy Rocznik ..., 1966, pp. 117-118].

An important element of agrarian transformation from 1945 to 1948 was the establishment of a dense network of state owned farms. According to the ideology of the Polish Workers' Party (PPR), they were supposed to be the instrument of the state to impact the market, to accumulate necessary reserves as supplies for urban centres and the army; they were also supposed to be centres of agrarian culture and agro-technical assistance for peasant farms. 
From 1950 to 1956, according to the Main Statistical Office data, there was a decrease in the peasant acreage of arable land by 1,875 thousand ha, i.e. by $23 \%$ of the total arable land. The number of peasant farms of more than 10 ha decreased from 180,000 to 120,000 , i.e. by $30 \%$ with a concurrent stagnation of agrarian structure of farms below 10 ha [Lewandowski, 2004, p. 69]. Individual farmers were not convinced about the compliance of the party's agricultural policy with their needs and aims to strengthen their farms, in particularly because as a result of an intensive development of industry, the share of agriculture in investment outlays of the state were minimum. In that period, socialised farms also suffered from shortages of production means and insufficient investment.

Both in Poland and in the Wrocław region, changes took place in almost all acreage groups (table 2). Considerably larger transformations took place in the agrarian structure of the Wrockaw region, where the number of farms of less than $2 \mathrm{ha}$ and in the group from 2 to $5 \mathrm{ha}$, increased by more than half in 1960. The growing tendency was visible also in the group of more than 10 ha, but the group of farms between 7 and 10 ha decreased from $33.4 \%$ in 1950 to $21.9 \%$ in 1960 . These were not desirable changes, since as a result of them, the number of micro and small size farms increased.

During the 6-year plan, many factors influenced the agrarian structure of Lower Silesia. As a result of many phenomena, including farmers joining production cooperatives, transfer of ownership of land onto the state and abandonment of farms, the number of individual farms and the acreage of land cultivated by them decreased. In Lower Silesia, the phenomenon of abandoning and leaving farms was the most intensified in the whole country; in 1950 the number of abandoned farms amounted to 4,140, in comparison with other regions of Szczecin - 606, Poznań 54, Koszlain - 1,015, Zielona Góra - 1,587 [Notatka z...., 1952, p. 104]. The number of applications submitted in 1950 for waiver of title to farms in the Wrocław region amounted to 5,953, while in the Szczecin region there were 1,771, i.e. three times fewer, in the Poznań region - only 99 which is almost 60 times less [Notatka z..., 1952, p. 106].

Another factor, which is also mentioned by F. Kapusta [1980, p. 129] was the problem of dividing larger farms into smaller ones to avoid excessive progression of services, and also the abandonment or transfer of ownership of the land to the state as a result of farmers joining farming cooperatives. From 1950 to 1955, the number of individual farms decreased from 133.3 thousand to 100.4 thousand, i.e. by $24.7 \%$, and the acreage of arable land - from 753.0 thousand ha to 560.5 thousand ha, i.e. by $25.6 \%$.

However, there was an increase of socialised farming in cultivating land from $30.8 \%$ in 1950 to $53.1 \%$ in 1955 . There was also a change in the internal structure of individual sectors of agriculture. Two sectors developed intensively, i.e. cooperative and state-owned farming. The number of production cooperatives increased from 1 in 1948 to 1,754 on 30.09.1956 [Kapusta, 1980, p. 130]. Agricultural production cooperatives were the most popular in Lower Silesia and constituted $16.7 \%$ of their total number in Poland. After October 1956, in the whole country, the process of 
their breakdown commenced. On 30th September 1956, out of 10,510 cooperatives in the country, 1,534 cooperatives joined the division of earnings for 1956. In Lower Silesia, 260 production cooperatives broke up already in October, in November 1,060 more, and in December - another 338. Therefore, during almost three months, 1,666 cooperatives broke up in Lower Silesia, i.e. 95\% of all previously existing. By 11th March 1957, there were only 93 cooperatives operating in Lower Silesia, including 34 cooperatives newly organised; they constituted $5.4 \%$ of the total number of production cooperatives as of 30.10.1956, when they amounted to 1,731 [Miernik, 2004, p. 36].

TABLE 3

Share of individual and socialised farms in arable land and in production from 1950 to 1955 (in \%)

\begin{tabular}{|c|c|c|c|c|c|c|}
\hline \multirow{2}{*}{ Year } & \multicolumn{2}{|c|}{ Individual farms } & \multicolumn{2}{c|}{ Production cooperatives } & \multicolumn{2}{c|}{ State-owned farms } \\
\cline { 2 - 7 } & $\begin{array}{c}\text { Arable } \\
\text { land }\end{array}$ & $\begin{array}{c}\text { Final } \\
\text { production }\end{array}$ & $\begin{array}{c}\text { Arable } \\
\text { land }\end{array}$ & $\begin{array}{c}\text { Final } \\
\text { production }\end{array}$ & $\begin{array}{c}\text { Arable } \\
\text { land }\end{array}$ & $\begin{array}{c}\text { Final } \\
\text { production }\end{array}$ \\
\hline 1950 & 89.6 & 93.4 & 0.8 & 0.5 & 9.6 & 6.1 \\
\hline 1951 & 84.9 & 90.2 & 3.2 & 2.3 & 11.9 & 7.5 \\
\hline 1952 & 83.9 & 88.8 & 3.4 & 3.0 & 12.7 & 8.2 \\
\hline 1953 & 80.4 & 83.0 & 6.7 & 6.7 & 12.9 & 9.3 \\
\hline 1954 & 78.7 & 83.3 & 8.2 & 7.0 & 13.1 & 9.7 \\
\hline 1955 & 77.3 & 81.5 & 9.2 & 8.0 & 13.5 & 10.5 \\
\hline
\end{tabular}

Source: own elaboration on the basis: [Rocznik...,1957, p.130; Rolniçy Rocznik..., 1966, p. 119].

Despite promoting at all costs various types of investments, loans and other forms of aid for Agricultural Production Cooperatives (RSP) and State Owned Farms (PGR) from 1950 to 1956, their economic performance was not too convincing. On the contrary, they were too weak economically to compensate for the insufficient agricultural production of individual farms. In the period of their peak development, production cooperatives covered ca. 9\% of arable land and provided $8 \%$ of final produce, while PGR's relatively covered $13.5 \%$ of arable land (most of them located in the Western and Northern Areas), and their share in the final produce amounted to $10 \%$. In 1955, earnings from agriculture were similar to those in 1950; they only grew minimally thanks to great provisions for the state. Therefore, an increasing number of people were determined to search employment opportunities outside agriculture or options to combine work in agriculture with employment in other economic sectors, mainly industry. Taking into consideration gross investment outlays in agriculture from 1950 to 1955, counted in billion Polish zlotys, the amounts designated for socialised economy in 1950 were double (2,1 billion $\mathrm{zl}$ ) in comparison to outlays for private sector (only 1.2 billion $\mathrm{zl}$ ). The worst example of private ownership was in 1954, when the outlays dropped to 0.9 billion $\mathrm{zl}$, and in socialised sector increased to 3.2 billon zlotys, to achieve in 1955 the amount of 4.2 billion zlotys in comparison to 1.6 billion $\mathrm{zl}$ for private sector 
[Hammerling et al., 1978, p. 217; Ryć, 1968, p. 137]. This situation demonstrates that the modest resources received by RSPs and PGRs prevented the development of a strong economic base and a creation of economically strong and successful socialistic large farms.

From 1950 to 1955, the animal production increased, mainly on socialised farms, where the indicator of the livestock number per 100 ha of arable land increased. Greater growth of animal production than plant production meant an increased share of animal breeding in the total agricultural production, from $42 \%$ in 1949 to $46.3 \%$ in 1955. In 1946, in the Wrocław region, there were 18.5 heads of cattle, 4.7 heads of pigs, 1.1 heads of sheep per 100 ha [Przekroje terenowe..., 1967, p. 578]. In 1950 , per 100 ha of arable land there were 32.6 heads of cattle, 33 heads of pigs and 5.1 heads of sheep, while in 1956 the numbers looked as follows: 38.5 heads of cattle, 55.1 heads of pig and 20 heads of sheep [Rocznik Statystyczny..., 1959, p. 202].

Taking into consideration cattle breeding in individual and socialised farms, in 1950 the livestock population per 100 ha of arable land amounted to 39.2 heads on individual farms and 21.5 heads in production cooperatives. In 1955, this number increased to 44 heads on individual farms, and in cooperatives it was 31.8 heads [Rocznik Statystyczny..., 1959, p. 203].

The usage of mineral fertilizers per 1 ha of arable land in production cooperatives was more than double in comparison to individual farms. Cooperatives, similarly to state owned farms used the largest volume of fertilizers. From 1954 to 1955, collective farms used $58.6 \mathrm{~kg}$ of pure NPK ingredient per 1 ha of plantation, which corresponded to $44.8 \mathrm{~kg}$ per 1 ha of arable land, while PGRs used correspondingly $59.2 \mathrm{~kg}(44.8 \mathrm{~kg})$ [Rocznik statystyczny..., 1957, p. 123]. In individual farming, the usage of fertilizers amounted to $28.1 \mathrm{~kg}$ per 1 ha of plantation which corresponded to $21.1 \mathrm{~kg}$ of 1 ha of arable land [Strużek, 1982, pp. 160-161]. From 1953 to 1956, collective farming used ca. 20\% of total supplies of fertilizers for cooperatives and individual farms [Rocznike Statystyczny..., 1956, p. 71].

With respect to mechanisation in agriculture, in 1950 in the Wrocław region there were 506 tractors (in physical units), in 1952 - already 1,637 units, and then in 1953 - 2,087 units, in $1955-2,885$ units, in 1956 this number increased to 3,343 in comparison to 22,039 units in the whole country in State Machinery Centres (POM) [Nowe zatozenia ..., 1956, p. 57]. The POMs in the Wrockaw region had the largest number of tractors. The level of mechanisation, or in fact of "tractorisation" of agriculture in Poland, counted with the acreage of agricultural land and arable farming per one statistical tractor, was on the level of developed European countries These numbers are not comparable due to the quality and power of tractors in Poland, as well as their technical condition, which was highly unsatisfactory.

\section{Conclusions}

This article is an attempt to indicate the most important factors determining the situation of agriculture in Lower Silesia from 1918 to 1939 and 1945 to 1956. 
It discusses issues important for agriculture, such as the dependence of economic and social position of agriculture on the policy of the state, unused economic potential and de-capitalisation of agriculture in Lower Silesia after 1945, impact of limitations for the development of individual economy created by the socialistic system in favour of the privileged socialised economy.

Considerations included in this paper first of all aimed at answering the question how the structure of agriculture which was shaped in a different political system, inherited technical plant and machinery, and agro-technical culture were adopted in new political and social conditions. The answer to this question is negative. Despite the fact that before 1945, Lower Silesia constituted one of the poorest provinces of the Reich, its agriculture was on a relatively high level thanks to a high agricultural culture in comparison to Poland of the pre-war times. The evidence of that was the amount of achieved harvest, indicators of fertilizers used in agriculture, agricultural plant and equipment available on farms, as well as electricity usage. The relatively high level of agriculture in Lower Silesia before World War II is also confirmed with the structure of plantations and livestock headage per 100 ha of agriculture land, as well as developed horticulture and fruit-growing.

Few conclusions can be formulated according to the research results. Agriculture in Lower Silesia was marginalized in subsidies from the German authorities from 1920 to 1930. Eastern Prussia, where the largest agricultural estates were located, received the largest amounts of subsidies of all eastern provinces; they amounted from several dozens to several hundreds of million of marks. For Lower Silesia, they ranged from one to less than ten million marks. The beginning of 1930s was not an easy period, either; the pauperisation of urban population weakened the demand for agricultural and food products; the decreasing percentage of people employed in agriculture increased the debt burden of mostly large estates, which on the one hand contributed to their breakdown and creation of numerous small ones. Another factor was their mechanisation. Changes introduced by the German state after 1933 brought solutions, which had a positive impact on increasing the production level. As a result, agricultural production increased three-fold, especially the production of rye and potatoes. Since the transport of those products further westward into the Reich was not profitable due to the cost of rail and road forwarding, the food processing industry developed in Silesia. It included mainly distilleries, processing of fruit and vegetables, dairy industry and sugar refineries.

The fact that the government in Poland was taken over by the communist and the country joined the so called Eastern Block, prevented further development of capitalistic agriculture in Lower Silesia. The agricultural structure created after the war was not adjusted to the farms that were taken over. The existing farming system was totally different from the social and political assumptions based on the agrarian reform and socialistic agriculture base in the communist Poland. Migration, resettlement and inflow of people to Lower Silesia after 1945 limited the possibility of an effective use of the existing potential of agriculture. As a result of the manner of "managing" agriculture in Lower Silesia in comparison to the pre-war times, in many respects its potential was not recovered. The pace of development of agricultural 
production in Poland from 1951 to 1955 was lower than in capitalistic countries of Western Europe, where the average annual growth of agricultural production amounted to $3.5 \%$, while in Poland it was $1 \%$.

The main reason to stop the development of agriculture from 1951 to 1955 was undoubtedly the insufficient production base of the national economy, which did not allow to meet the demand of agriculture for fertilizers, machines, tools and crop protection products. Also, an unfair agricultural policy had a serious impact on rural areas. For example, it was manifested in violating the principle of voluntariness in creation of production cooperatives, excessive economic pressure on peasant farms, which was supposed to accelerate the process of creating cooperatives in rural areas, and also not always rightly understood fight with the kulaks (i.e. affluent peasants). As a result, all that contributed to a lack of prospects for the development of individual peasant farms and caused a number of negative phenomena, such as stopping investment processes, and as a result, de-capitalisation of farms, or numerous cases of abandoning farms. At the same time, as a result of a great demand for labour in cities due to the industrialisation of the country, agriculture suffered from a great shortage of hands to work.

\section{References}

Bechtel H., 1933/1934, Die gegenwärtige Wirtschaftslage im reichsdeutchen Schlesien, [in:] Schlesisches Jabrbuch fuer deutsche Kulturarbeit im gesamtschlesischen Raume, Wilhelm Gottlieb Korn Verlag, Breslau.

Brożek A., 1966, Ostflucht na Ślasku, Wydawnictwo Śląsk, Katowice.

Buławski R., 1946, Wyniki spisu z 17 V 1939 r., Materialy Statystyczne Biura Studiów Osadniczo-Przesiedleńczych, Wydawnictwo Uniwersytetu Jagiellońskiego, Kraków, z. 1.

Czapliński M., 2007, Ślask od piernszej po koniec drugiej wojny światowej, [w:] Historia Ślaska, Czapliński M., Kaszuba E., Wąs G., Żerelik R. (red.), Wydawnictwo Uniwersytetu Wrocławskiego, Wrocław, t. 1.

Fensch H.L., 1932, Die Entwicklung der landwirtschaftlichen Betriebsergebnidsse seit der Neugestaliung der Währung, Dt. Verlag Ges., Berlin.

Fiedor K., 1965, Dolny Ślask w gospodarce niemieckiej i polskiej, „Śląski Kwartalnik Historyczny Sobótka", nr 20/1a.

Gleitze B., 1956, Ostdeutsche Wirtschaft. Industrielle Standorte und volkswirtschaftliche Kapazitäten des ungeteilten Deutschland, Duncker\&Humblot, Berlin.

Hammerling Z., Luczak A., Markiewicz A., 1978, Życie społeczno-polityczne i gospodarcze wsi w Polsce Ludowej, Książka i Wiedza, Warszawa.

Jagielski A., 1958, Produkcja, podaż i ceny produktón rolnych na Ślasku, [w:] Studia i materialy z driejón Ślaska, Popiołka K. (red.), Wydawnictwo Zakładu Historii Śląska Państwowej Akademii Nauk, Wrocław, t. 2. 
Jagielski A., 1958a, Zmiany strukturalne w rolnictwie Ślaskim 1907-1939, [w:] Studia i materialy z driejón Ślaska, Popiołka K. (red.), Wydawnictwo Zakładu Historii Śląska Państwowej Akademii Nauk, Wrocław, t. 2.

Kaliński J., 1995, Gospodarka Polski w latach 1944-1989: przemiany strukturalne, Państwowe Wydawnictwo Ekonomiczne, Warszawa.

Kapusta F., 1980, Przemiany spoteczno-ekonomiczne wsi dolnoślaskiej w latach 1945-1976, Wydawnictwo Zakład Narodowy im. Ossolińskich, Wrocław.

Kłusek M., 2013, Państwony Bank Rolny. Dokumenty do driejón Państwowego Banku Rolnego 1945-1948, Wydawnictwo i Drukarnia „Drukrol”, Kraków, t. 2.

Kokot J., 1955, Przebudowa gospodarcza Ślaska. Gómy Ślask, Prace i materiały geograficzne, Kraków.

Kościk E., 2010, Migracje ze wsi do miast w latach PRL ze sz̨crególnym uñaglednieniem Dolnego Ślaska, [w:] Modernizacja cazy pozorna modernizacja. Spoteczno-ekonomiczny bilans PRL 1944-1989, Chumiński J. (red), Wydawnictwo Gajt, Wrocław.

Kouli Y., 2018, Dolny Ślask1936-1956. Szybki rožoój i nieudana odbudowa. Wplyw wiedsy na produkcje przemystowa, Wydawnictwo Uniwersytetu Warszawskiego, Warszawa.

Lach W., 1965, Rolnictwo Dolnego Ślaska, Powszechne Wydawnictwo Rolnicze i Leśne, Warszawa.

Lewandowski S., 2004, Formy dyskryminacji i metody ograniczania aktywności chtopów przez. komunistón w latach 1956-1990, [w:] Represje wobec wsi i ruchu ludowego (1956-1989), Gmitruk J., Nawrocki Z. (red), Wydawnictwo Muzeum Historii Polskiego Ruchu Ludowego, Instytut Pamięci Narodowej, Warszawa, t. 2.

Meyer K., 1939, Gefügeund Ordnung der Landwirtschaft, Reichsnährstandvlg, Berlin.

Miernik G., 2004, Dekolektywizacja wsi w Polsce w latach 1956-1957, [w:] Represje wobec wsi $i$ ruchu ludowego (1956-1989), Gmitruk J., Nawrocki Z. (red.), Wydawnictwo Muzeum Historii Polskiego Ruchu Ludowego, Instytut Pamięci Narodowej, Warszawa, t. 2.

Notatka z.grudnia 1952 r. w sprawie zrzeczen sie przez osadnikón gospodarstw rolnych, 1952, Archiwum Akt Nowych w Warszawie, Komitet Centralny Polskiej Zjednoczonej Partii Robotniczej, sygn. 237/XII - 145.

Nowe założenia polityki rolnej, 1956, Archiwum Państwowe we Wrocławiu, Komitet Wojewódzki Polskiej Zjednoczonej Partii Robotniczej, sygn. 1417.

Ordyłowski M., 1999, Wieś dolnoślaska w latach 1945-1956. Wtadza a spoleczeństwo, Wydawnictwo Akademii Wychowania Fizycznego we Wrocławiu, Wrocław.

Pismo Departamentu Przebudony Ustroju Rolnego o reformie rolnej w Narodonym Planie Odbudowy Gospodarczej z dnia 24 lipca 1948, 1948, Archiwum Akt Nowych, Ministerstwo Rolnictwa i Reform Rolnych II, sygn.1901.

Pismo o reformie rolnej z dnia 28 lipca 1948 r., 1948, Archiwum Akt Nowych, Ministerstwo Rolnictwa i Reform Rolnych II, sygn. 1901.

Pismo Petnomocnika Rzqdu RP, obwód XXV w Bystraycy w sprawie nienystarczajacej liczby koni z dnia 24 kwietnia 1946 r., 1946, Archiwum Państwowe we Wrocławiu, Urząd Wojewódzki Wrocławia, Wydział Osiedleńczy, sygn. IX/113.

Pismo z. 13 IV 1931 r., 1931, Archiwum Państwowe we Wrocławiu, Akta Urzędu Kultury Rolnej we Wrocławiu, Akten des Landeskuluramtes zu Breslau, sygn. 94. 
Przekroje terenowe 1945-1965, 1967, „Statystyka Regionalna”, GUS, nr 7.

Ročnik Statystyczny m. Wroctawia i wojewódz̨twa wroctawskiego 1958, 1959, GUS, Wrocław.

Rocznik Statystyczny ₹.1947 r., 1948, GUS, Warszawa.

Rocznik Statystyczny z 1956 r., 1957, GUS, Warszawa.

Rocznik Statystyczny z. 1957 r., 1958, GUS, Warszawa.

Rocznik Statystyki Rolniczej 1938, 1939, GUS, Warszawa.

Rolniçy Rocznik Statystyczny 1945 - 1965, 1966, GUS, Warszawa.

Ryć K., 1968, Sposiycie a wzrost gospodarçy Polski, Książka i Wiedza, Warszawa.

Statistisches Jahrbuch fur das Deutsche Reich, 1938, https://www.digizeitschriften.de/ $\mathrm{dms} /$ toc/?PID=PPN514401303_1938 [date of entry: 12.04.2019].

Statistisches Jahrbuch fur das Deutsche Reich, 1939, https://www.digizeitschriften.de/ $\mathrm{dms} / \mathrm{toc} /$ ?PID=PPN514401303_1939 [date of entry: 05.03.2017].

Statystyka dotyczqca inwentarza symego $i$ zniszczeń wojennych 1946 r. Pismo do Ministerstwa Rolnictwa i Reform Rolnych, Departament Prz̨ebudowy Ustroju Rolnego w Warszawie z. dnia 18.09.1946 r., w pismie jest informacja, że na Dolnym Ślasku po wojnie, stan pogtowia innentarza syywego oceniany jest na 10\%, 1946, Archiwum Państwowe we Wrocławiu, Urząd Wojewódzki Wrocławia, sygn. XX/147.

Straszak-Chandoha S., Merta-Staszczak A., 2018, Podstawowe problemy rolnictwa w Polsce w okeresie dwudriestolecia miedsynojennego, [w:] Gospodarczy bilans otwarcia polskiej niepodległości w 1918 r., Głowiński T., Zawadka M. (red.), Wydawnictwo Gajt, Wrocław.

Strużek B., 1982, Rozwój socjalistycznych form gospodarki rolnej, Ludowa Spółdzielnia Wydawnicza, Warszawa.

Styś W., 1948, Rolnictwo na Dolnym Ślasku, Oblicze Ziem Odzyskanych. Dolny Ślask. Tom I: Pryyroda i gospodarka, Wydawnictwo Książnica - Atlas, Wrocław - Warszawa.

Was ist mit Polens Agrarfonfurrenzc? Schlesische Provin₹korrespondens, 1928, Archiwum Państwowe we Wrocławiu, Rejencja Wrocławska - Akta Rolne, sygn. 15889.

Zagadnienie podziatu zagród wielorodzinnych na terenach Ziem Odšyskanych, 1948, Archiwum Akt Nowych, Ministerstwo Ziem Odzyskanych, sygn. 2201. 